City University of New York (CUNY) CUNY Academic Works

\title{
The White Album As Neo-Victorian Fiction of Loss
}

Lucas Kwong

CUNY New York City College of Technology

\section{How does access to this work benefit you? Let us know!}

More information about this work at: https://academicworks.cuny.edu/ny_pubs/723

Discover additional works at: https://academicworks.cuny.edu

This work is made publicly available by the City University of New York (CUNY).

Contact: AcademicWorks@cuny.edu 


\title{
The White Album as Neo-Victorian Fiction of Loss
}

\author{
LUCAS KWONG
}

\begin{abstract}
While much has been written about Sgt. Pepper's celebration of high Victorian culture, little scholarship, if any, has focused on the White Album's relationship to the late Victorian period. This paper examines The Beatles through the lens of what Victorian studies scholar Stephen Arata has called "fictions of loss," a body of fin de siècle texts depicting intertwined processes of "national, biological, [and] aesthetic" decline. I argue that the White Album can be read alongside Dracula and She as a "fiction of loss," revealing the degree to which a sense of "irretrievable decline" returned to haunt Britain in the late Sixties. Indeed, decline and fall comprise one of The Beatles's major concerns, not only because the album documents the band's nascent breakup, but also because it finds the band addressing (and often satirizing) a constellation of fin de siècle themes, newly relevant at midcentury: fears of reverse colonization ("Back In The USSR"); half-ironic fascination with colonial adventurism and "Eastern" enlightenment as correctives to decline ("The Continuing Story of Bungalow Bill," "Dear Prudence"); Decadent critiques of over-interpretation ("Glass Onion"); nightmares/fantasies of apocalyptic destruction ("Helter Skelter," "Revolution 9"), and representations of animal bodies ("Piggies," "Yer Blues"). If Sgt. Pepper consciously invoked Victorian nostalgia, the White Album evokes fin de siècle motifs unconsciously, responding to their resurgence in the Beatles' time.
\end{abstract}

KEYWORDS: The Beatles, Victorian studies, cultural memory, the White Album

DOI: 10.5325 /intelitestud.22.1-2.0052

INTERDisCiplinary Literary StUdies, Vol. 22, Nos. 1-2, 2020

Copyright (C) 2020 The Pennsylvania State University, University Park, PA 
Postmodernity, according to much Beatles scholarship, defines the White Album. Framed as a kind of soundtrack to Roland Barthes's contemporaneous "death of the author," The Beatles thus highlights the group's attunement to their present.

But what of its relationship to the past? ${ }^{1}$ In what follows, I argue that the White Album functions as a spiritual sequel to Sgt. Pepper, by documenting the Victorians' continued influence on Sixties Britain. In Fictions of Loss in the Victorian Fin de Siecle: Identity and Empire, Stephen Arata explains how late Victorian texts represented a pervasive sense of "irretrievable decline" (i) and "abiding loss" (1). In another era when decline loomed large, so did the White Album.

In parsing The White Album's late Victorian underpinnings, this article presumes that the narratives of that era offer a means of understanding popular music. As Keith Negus writes, popular music relies on narrative not simply via "story-songs," such as "Rocky Raccoon," but also through any song's relationship to other songs, as well as to the stories a culture tells itself. Noting how "I Want to Hold Your Hand" responds to Sixties girl groups' pleas for male affection, Negus describes the song as "one example of how songs continually enter narrative dialogues with other songs" (374). Such intertextual engagement supplements any given song's intercontextual capacities, its ability to "link together a particular series of events, experiences, and moments in time" (388). Examining a song's narratival qualities, then, can involve three sites of analysis: a discrete set of music and lyrics (the microdrama of Bungalow Bill); the relationship between that song and others (the narrative dialogue between "Bungalow Bill" and the track that follows it); and the song's participation in "wider cultural dialogues through which historical understanding is narrated" (Bungalow Bill's relationship to Sixties Britain's postimperial melancholy and the Victorian hegemony that produced it). The following article examines all three fronts, tracing how specific tracks on the album, and their relationship to one another, draw upon cultural narratives of loss dating to the nineteenth century. In doing so, it shows that the album's famous descent into darkness outlines the shadow that 1898 cast on 1968 , via a resurgent obsession with decline and fall. ${ }^{2}$

\section{FICTIONS OF LOSS, TOLD AND RETOLD}

In Fictions of Loss, Arata identifies three lenses through which fin de siècle Britain contemplated its downfall: sociopolitical, physiological, and artistic. At its limit of territorial expansion, the British empire inspired 
anxiety about threats to its hegemony, particularly via comparison to the Romans. ${ }^{3}$ Moreover, as Jeffrey Franklin examines in The Lotus and the Lion, Buddhism seemed to threaten a religious "counter-invasion," since its vitality, and compatibility with evolutionary science, made it "the first non-Christian religion to be considered a threat to the West in its home territory" (4). Meanwhile, German and American industrial competition triggered the "first serious burst of declinism" in British economic policy (Tomlinson 229), evidenced in a Royal Commission's 1886 warnings that "foreign competition" would "choke the living fountain of our wealth, our social wellbeing, and our national strength" (quoted in Supple 331).

Alarm about the body politic produced concern for actual bodies. As Edward Said writes, "the connection . . . between empire and the nation's health" inspired Robert Baden-Powell's founding of the Boy Scouts, through whom physical discipline would train Britain's future defenders. Declinist attention to the body also surfaced in the work of such scholars as Max Nordau, whose Degeneration treated cultural trends as "manifestations of physiological ailments" (Baldwin 104), and Cesare Lombroso, whose concept of "criminal atavism" cast criminality as a biological vestige from an earlier stage of evolution (Mazarrello 98). Proscriptions on miscegenation, as exemplified in the Anthropological Review's 1869 recommendation "that any Englishman helping to reproduce racial hybrids should be severely punished," also symptomatized declinist anxiety (Harris). ${ }^{4}$ At the same time, many imagined that Britons in India could prevent imperial senescence, "combin[ing] the intellectual maturity of the Westerner with a physical and emotional vigor no longer found in the aging West" (Arata 159). ${ }^{5}$

Finally, cultural commentators worried about artistic decline. Arata cites critic Robert Buchanan's attacks on Rudyard Kipling and Christina Rosetti, whose violations of "romantic sensibility" and "classical realism" activated "a degeneracy lying dormant in the public body" (Arata 173). The perceived enmeshment of texts, bodies, and the nation meant that critics regularly cited "literary works . . . as evidence of . . . degenerative illness" (18), and, by extension, of civilizational decay. Political, biological, and aesthetic degeneration thus became "mutually implicated" in late Victorian thought (2). In examining the "fictions of loss" arising from degeneration theory's prevalence, Arata synthesizes a range of Victorianist scholarship; in relying on Arata's argument, this article takes for granted a phenomenon widely recognized as characteristic of the period. ${ }^{6}$

In context, then, the White Album can be seen as the culmination of a decade in which Britain reacquainted itself with concepts of interlocking 
decline. As Callum Brown has shown, the 1950's saw an efflorescence in church growth and "a barrage of official and popular discourses" pushing professional women toward "home and hearth" (171); he writes, "The 1950 os were about perfecting Victorian values and finally distributing their fruits" (175). However, after the Suez Canal crisis of 1956, questioning the fate of the Empire? - and, by extension, Britain's neo-Victorian society? - became "proper and timely," in historian A. P. Thornton's phrasing (quoted in Ward 9). Such questioning crystallized in a spate of "state of Britain" books published between 1958 and 1964. ${ }^{7}$ If imperial nostalgia shadowed "perceptions of national degeneration" (Ward 10), so did the notion of a bygone era of economic growth, putatively mirrored in the "dynamism of the Western European economies" ("Thrice Denied" 235). Commentator Anthony Hartley's discussion of the "intellectually enervating and morally void" influence of mass media (175), combined with his descriptions of England as a "weakened organism" prone to "enfeeblement" (235), emblematizes how easily cultural malaise could, once more, entail artistic and bodily decay.

Specifically, anxieties about nation, art, and the body converged in critiques of youth culture and its music. For British adults, rock 'n' roll threatened the Americanization of musical tastes. ${ }^{8}$ Moreover, as Roberta Schwartz notes, critics' "racially based" attacks on the genre (61) decried the "primitive tom-tom thumping" of Africa and its possession of young British bodies (quoted in Schwartz). Familiar from American reactions to rock 'n' roll, such fears took on added valence in light of imperial history, as seen in one journalist's description of rock music as reverse colonization: "We sometimes wonder whether this is the Negro's revenge" (quoted in Schwartz 61). Disdain for rock 'n' roll was bound up with moral panic about youth cultures whose very bodies signaled the nation's doom. In the Fifties, the Teddy Boys' violence compounded the offense of their signature drape jackets, "a blasphemous mixture of orthodox British dandyism and Yank style" (Chibnall 74). In the early Sixties, rivalry between "mods" and "rockers" assumed mythological proportions, as newspapers' breathless coverage of the groups' resort town clashes elicited commentary on the "spreading social disease" of hooliganism (Cohen 63), which signaled, in the words of one editorial, "something rotten in the state of Britain" (quoted in Cohen 62). ${ }^{9}$ For alarmists, the infected bodies and primitive music of such youths portended national apocalypse.

By 1968, the Beatles had weathered a shifting relationship to declinism. Early in their own career, some interpreted their rise pessimistically: "The 'Beatlemania' and irrationality that so many are exhibiting show that 
our education and training are a leaving mental and spiritual vacuum" ("Ballyhoo" 1). A 1963 concert review invoked the language of social disease, likening audience ecstasy to "an infectious screaming virus" (quoted in Creasy). While some undoubtedly used such language ironically, genuine concerns from this era are evidenced in a "well received" article in The British Journal of Social and Clinical Psychology, titled "Beatlemania: A Study in Adolescent Enthusiasm" (Taylor 2). However, the Beatles quickly transformed from degenerates into establishment darlings, with the royal family praising their 1963 Royal Variety performance, politicians competing for their approval in 1964, and the Queen conferring MBE medals on them in $1965 .{ }^{10}$ Solidifying British pop's status as "a kind of global musical lingua franca," the Beatles assured the nation of its international influence after empire (Coopey, "Popular Imperialism").

This proximity to the cultural mainstream naturally led to Sgt. Pepper's fondness for Victoriana. Terrence Riley's description of Sgt. Pepper as a "neo-Victorian text," fascinated by nineteenth century British cultural artifacts, aptly expresses the way that Pepper tapped into a widespread affection for the nineteenth century. ${ }^{11}$ Such an era of lost national greatness would have proved even more appealing in 1968, when degeneration dominated the national mood. The year began with a government-sponsored campaign borne out of concerns about the pound's devaluation (about which more anon). Prime Minister Harold Wilson announced military withdrawal from Southeast Asia, underscoring Britain's weakened postimperial power (Longinotti 318). An influx of immigrants from the Commonwealth inspired Conservative MP Enoch Powell's "Rivers of Blood" speech, a xenophobic rant that won admiration from White Album guest guitarist Eric Clapton (Adelt 76-77). Meanwhile, the Dangerous Drugs Act of 1967 had given police extra powers to combat drugs, which also inspired Sgt. Norman Pilcher's arrest of Mick Jagger and Keith Richards that year (Womack 728). (Lennon himself would be raided in October 1968, followed by George Harrison in 1969 [ibid.]). Pilcher's focus on rock stars underscored pop music's perceived degeneracy, with the Lord Chief Justice calling for stricter policing of "beat clubs" where drugs were supposedly trafficked (Simonelli 116).

On the White Album, then, the Beatles had ample reason to summon the Victorian era once more. Indeed, the initial title for The White Album was A Doll's House, Henrik Ibsen's 1879 play about a woman's disillusionment with Victorian mores (Lewisohn 163). (One might think of the album as a companion to The Kink's 1969 album, Arthur [Or The Decline and Fall 
of the British Empire.]) Instead of reviving Sgt. Pepper's nostalgia, however, the White Album engages with the period by representing loss in terms that suffused late Victorian discourse. The following sections examine key moments on the White Album alongside fin de siècle fictions of loss, before assessing how sociopolitical, aesthetic, and biological decay converge at its conclusion.

\section{REVERSE COLONIZERS AND EASTERN RENEWAL: SOUNDING THE DEGENERATING “ALL"}

While the cheery pastiche of "Back in the USSR" might seem an odd expression of national decline, most Beatles scholars agree that the government-sponsored campaign "I'm Backing Britain" inspired the opening track. ${ }^{12}$ Rooted in concerns about a flagging economy, "I'm Backing Britain" sparked such a plethora of Union Jack-embossed paraphernalia that the New Statesman published a piece called "Put Out Less Flags" (85). ${ }^{13}$ The pervasiveness of such skepticism meant that "Back In The USSR" was not even the only "I'm Backing Britain" sendup released in 1968. The film Carry On Up the Khyber satirized the late Victorian colonial establishment by invoking the campaign: the final shot shows a British flag emblazoned with the words “'I’m Backing Britain" (Izhar, 177).

This juxtaposition of past and present also characterized the emergent genre of "empire plays," whose articulation of "public concerns about immigration, national decline and ... 'permissive society" proceeded via shocking depictions of empire (Poore, 46). However, "Back In The USSR" skewers contemporary politics not through historical references, but through an updated Victorian trope: the "reverse colonizer" who does to England as England has done to the world. Written from the perspective of "a spy who's been in America a long, long time" (McCartney, "Interview with Radio Luxembourg"), the lyrics praise the USSR in American slang: "Man, it's good to be back home." Like its fin de siècle predecessors, the song conjures an Eastern enemy who can "pass" for Western. Dracula absorbs books on "English life and customs and manners" to blend in with the London crowd, from whom he will "create an ever-widening circle of semi-demons" (Stoker 49); She's white queen Ayesha, presiding in Africa, resolves to "go to England ... [and] assume absolute rule over the British dominions" (Haggard 249). Dracula's and Ayesha's appearances on British movie screens in 1968 sated an ongoing appetite for these avatars of 
imperial anxiety. ${ }^{14}$ Indeed, lest British listeners consider themselves exempt from infiltration, the spy departs America via "BOAC", the British Overseas Airways Corporation.

Condemned by the John Birch Society as subversive (MacDonald 309), "Back in The USSR" offers less a celebration of Soviet communism than a riposte to nationalist fantasies, set to an all-American teenage soundtrack: Chuck Berry and the Beach Boys provide the musical idiom for this ode to the Soviet republic. ${ }^{15}$ Played in a comic vein here, the prospect of an alliance between youth culture and foreign subversion drove British conservatives to consternation. ${ }^{16}$ Where the album's first track presents an Eastern spy imitating America's youth, though, its second presents a British youth immersed in the East. "Dear Prudence" makes no explicit reference to the song's origins at an Indian ashram, but the song's opening jet engines (echoing the beginning of "Back In The USSR"), combined with its arrangement, evoke the Beatles' sojourn to the Maharishi Mahesh Yogi's rural commune. ${ }^{17}$ Acoustic guitar arpeggios recall the fingerpicking of fellow Maharishi disciple Donovan (Kimsey 77), while "dronelike guitars," in Walter Everett's phrasing, render it "as 'Indian' as a Lennon composition ever got” (168).

Yet while the sequence of "Back In The USSR" and "Dear Prudence" could suggest a plane ride from the USSR to a scene further East, it equally suggests a westward journey: arriving from India, Lennon offers enlightenment to a cautious England personified in "Prudence," one of many "traditionally English female names" on the record (Riley 257). Promising oneness with the cosmos- "The sun is out, the birds will sing/That you are part of everything" - "Dear Prudence" evokes "Oriental" influence returning to Britain, a contemporaneous concern that revisited fin de siècle apprehensions about religious counter-invasion. ${ }^{18}$ For example, Bram Stoker portrays Dracula as an avatar of "Eastern superstition" (Arata 122), inducing the trance state that many Victorian Christians attributed to Buddhism and Hinduism: when Mina Harker falls under Dracula's spell, not even thoughts, but mere "things [begin] to whirl through [her] brain" (241). ${ }^{19}$

While Dracula's eroto-spiritual threat may be audible in the hints of seduction in "Dear Prudence" (tinged with the menace of then-novel guitar distortion), the song's ambivalence?-evident in its "circling four-chord sequence" (Macdonald 310), irregular drumbeats that "draw out the tension" (Riley 263), and the unanswered question bookending its lyrics?-betrays closer kinship with works like Marie Corelli's Romance of Two Worlds, H. Rider Haggard's She sequel Ayesha, and Rudyard Kipling's Kim..$^{20}$ Jeffrey Franklin points out that Corelli's and Haggard's novels equivocate on the 
question of Eastern mysticism's capacity to forestall the West's decline: both "made use of certain adaptations of reincarnation and karma" (90) while critiquing the Buddha as "unacceptably passive for Westerners" (119). "Dear Prudence" stops short of valorizing India-besotted youths as heralds of a "brand new day"? - not because they espouse "unacceptably passive" doctrines, but because they remain no match for convention. Prudence's position parallels that of Kim, Kipling's Anglo-Indian protagonist, in the novel's final lines. His mentor, a Buddhist lama, invites him on a spiritual journey to "free [him] from all sin" (289); yet Kim, a hero of the colonial establishment, gives no response at the novel's close. So, too, does "Dear Prudence" end with Lennon's invitation fading in the face of Prudence's silent stasis.

Later on Side One, “The Continuing Story of Bungalow Bill” frames rejuvenation from the colonial fringes not as wistful impossibility, but as cruel absurdity. While "Bungalow Bill" fictionalizes an encounter between a tiger and a wealthy American whom the Beatles met at Rishikesh (Inglis 132), the song's depiction of a "mighty tiger" who takes "Bill and his elephants ... by surprise," only to get "zapped . . . right between the eyes," also resembles Rudyard Kipling's semi-comedic tales of soldiers, missionaries, and colonial administrators in British India. (One such story, "The Tomb of His Ancestors," even features the shooting of a tiger "between [its] saucer-like eyes," 150). ${ }^{21}$ Moreover, the "all-American" Bill is a "Saxon mother's son," a phrase recalling Victorian discourse about America as an extension of "Greater Britain," where, as in India, Anglo-Saxonry could regain strength. ${ }^{22}$ But Bill, future of the race, is a coward: his mother needs to "butt in" in his defense when "children" (possibly an ironic ventriloquization of British condescension toward colonial subjects) inquire "if to kill was not a sin." Bill's "Captain Marvel" antics mask a childish inability to relinquish fantasies of redemptive violence: an inability to accept loss, whether of colonial glory or of hope for Greater Britain.

While the album generally lacks interstitial gaps, John's spoken "Eyup" establishes particular continuity between "Bungalow Bill" and "While My Guitar Gently Weeps," linking the former track's ending applause with the latter's opening piano notes. As a single musical unit, "Bungalow Bill”/“Gently Weeps" reverses Marx’s dictum that history repeats itself "first as tragedy, then as farce": Lennon's song treats the loss of political naivete comically, Harrison's tragically. Against a descending chord progression, Harrison describes "look[ing] at you all" to "see the love there that's sleeping"; the next line, "I look at the floor and I see it needs sweeping," casts dormant love as a sign of entropy. While the line "I look at the world" 
suggests 1968's global tumult, the song also reads as an implicit commentary on the preceding track. Indeed, the phrase "I look at you all," repeated at the song's conclusion, inverts the dynamic of the chorus of "Bungalow Bill": where the latter involves a group addressing an individual ("Hey Bungalow Bill, what did you kill?"), the former finds Harrison addressing a crowd? perhaps even the crowd of "Bungalow Bill," chastised for either delighting in Bill's violence or for presuming its own moral superiority. Juxtaposed with Harrison's lamentation, Bill's attempt at Anglo-Saxon heroics, and the collective's fascination with what he has killed, become emblems of a degenerating "all."

The spectre of collective decay resurfaces throughout the album: on "Piggies," Harrison metaphorizes the underclass's deteriorating prospects ("For all the little piggies, life is getting worse"); on the downtempo revision of the single "Revolution," the latter's confidence that future society will be "alright" is replaced with a diffident murmur; and, as explained later in this article, "Helter Skelter" and "Revolution 9" deliver aural apocalypses. This focus on sociopolitical decay, however, supplements a corollary fixation with artistic decline, echoing late Victorian representations of decadent artistry.

\section{POST-PEPPER EXPECTATIONS AND THE BEATLES' DECADENT TURN}

Even as Sgt. Pepper glorified Victorian comforts, it repositioned the Beatles as threats to teenage rectitude. As David Simonelli has documented, 1967 to 1968 saw an array of journalists, critics, lawmakers, and citizens decrying drug use among musicians (116). ${ }^{23}$ In this climate, "Lucy in the Sky with Diamonds" and "A Day in the Life" were both banned by the BBC for apparently endorsing drug use, while "With A Little Help from My Friends" and "Fixing a Hole" alarmed others for the same reason (Norman 497-98). A June 1967 interview, in which a reporter frets that Paul McCartney had "encouraged [his] fans to take drugs," underscores how, once again, the group appeared as a corrupting influence ("Interview with ITV"). Nor were drugs their only tool of corruption: articles such as a People editorial titled “Think Again, Beatles!" chastized them for leading "millions of youngsters" to "Eastern pseudo-religion" (10).

Those unconcerned with drugs and meditation had other reasons to find the Beatles disappointing in 1968. Admirers like Kenneth Tynan had 
hailed Pepper as "a decisive moment in the history of Western Civilization" (quoted in Womack 816); Lindberg et al. observe the album's praise from critics with "'highbrow' accreditory power," a watermark in rock music's emergence as art (118-19). When the December 1967 film Magical Mystery Tour opened to disastrous reviews, then, the "critical drubbing," in Kenneth Womack's phrasing, would have especially stung (322). ${ }^{24}$ Moreover, the single version of "Revolution" elicited scorn from the left upon its release in August 1968, with the magazine Black Dwarf accusing the Beatles of diffidence to the need for change (Tranmer 98). Faulted on the right for hedonism, the Beatles also stood accused of creative exhaustion and political timidity.

Beset by this panoply of charges, the Beatles faced a predicament familiar to that of fin de siècle artists. The Decadents scorned their predecessors' emphasis on objective reality, instead viewing art as a celebration of subjective moments, what Walter Pater called "impressions unstable, flickering, inconsistent" (153). Decadence thus garnered a reputation for "put[ing] the parts above the whole," supposedly encouraging an inversion of social order (Potolsky 100). As Allon White writes, this reputation sparked a "growth of 'symptomatic reading"' (5), as if art could be used to diagnose pathology: at Oscar Wilde's trial, The Picture of Dorian Gray functioned analogously to "A Day in the Life" and "Lucy in the Sky with Diamonds," thinly veiled evidence of deviance. Meanwhile, polemics like William Watson's “The Fall of Fiction" argued that non-Decadent authors contented themselves with minor fantasies, where their mid-Victorian predecessors had offered realist surveys of human nature (Arata 90). In 1888, critic Andrew Lang weakly defended his contemporaries: "We have not a Thackeray, we have not a Dickens. But have we not ... the small change of those authors?" (quoted in Arata 90). On the White Album, the Beatles join their Decadent predecessors by challenging listeners given to symptomatic reading, as well as choosing an aesthetic of "small change" and "impressions unstable."

To be sure, symptomatic reading fuels the allusions of "Glass Onion" to other Beatles songs, which, in Lennon's own telling, ridicule the "gobbledegook" (quoted in Womack 328) that Pepper's lyrics had generated among both fans and critics. While lines such as "Here's another clue for you all/The Walrus was Paul" could tease both sympathetic and suspicious listeners, the drug allusions of "Fixing a hole in the ocean/Trying to make a dovetail joint" certainly bait the latter. Meanwhile, "Looking through the bent-back tulips/To see how the other half lives" implicitly accuses bourgeois listeners of voyeuristic interest in a bohemian underclass. Lennon's 
prankish ethos recalls Oscar Wilde's distribution of green carnations at a play; asked what the carnations meant, he answered, "Nothing whatever, but that is just what nobody will guess" (qted in Arata 67). "Oh yeahs" in the bridge, accompanied by an ascending chord progression, convey Lennon's own glee in barraging listeners with red herrings.

That barrage also recalls British decadents' narrative depiction of symptomatic readers. In Wilde's The Picture of Dorian Gray, the artist Basil Hallward's belief that "character can be read off the body"? - in other words, his use of interpretation to uncover secret vice? - "proves inadequate to the world [he] inhabits," since, as Arata points out, Wilde's is a world bereft of secret selves awaiting exposure (Arata 62). So, too, does Arthur Machen's Decadent novel The Hill of Dreams include a satirical portrait of a critic "fulminat[ing] against the 'abandoned artist and the scrofulous stylist" (Valentine 22-23). Meanwhile, Jessica DeCoux observes that Marie Corelli's Wormwood: A Drama of Paris (1890) features a proxy for bourgeois readers of Decadent literature, through whom "the (English) reader [is drawn] into self-recrimination." "Glass Onion" thus assumes the combative posture Decadent writers took toward critics, via "textual strategies [that] interfere with the boundaries and borders . . that criticism normally relies upon to make its judgments" (Constable et al., 11). In the song's closing "strings [that] slide their notes menacingly downward" (Rybaczewski, "Glass Onion History”), one practically hears declinist critics shuffling away, their judgments defeated. ${ }^{25}$

Meanwhile, Side 2's sequence interrogates the expectations raised by Pepper. Such expectations directly descend from those of critics, writing in the 188 os and 1890 os, who longed for what William Watson called the "old merits of fulness and 'body" that marked the mid-Victorian novel (quoted in Arata 89). On that basis, Robert Buchanan heralded Thomas Hardy as the "one living novelist who inherits the great human tradition" (24). ${ }^{26}$ As Arata observes, Dr. Jekyll and Mr. Hyde and Kipling's The Light that Failed both tackle this nostalgia for an earlier era of "great" art, whether via Hyde's expert forgery (the monster can also mimic great writing) (48-50) or in The Light That Failed's parody of Dickensian tropes (172-73). Elsewhere, in She, H. Rider Haggard implicitly asserts continuity between his boy's adventures and mid-Victorian realism: Arata notes that the protagonist's genealogy includes one "Dorothea Vincey," combining the names of characters in George Eliot's Middlemarch (104). These texts critique the presupposition undergirding disappointment with them, that is, that they lacked the complexity, scale, and elevated subject matter germane to Dickens and Eliot. 
In elevating those very qualities in musical form, Sgt. Pepper's admirers displayed their unwitting inheritance of Victorian aesthetic ideals. Side 2's sequence, which arguably cements the album's reputation as a set of improvisatory curios, joins Stevenson, Kipling, and Haggard in rejecting those ideals. During a marathon session on October 16-17, 1968, Lennon and McCartney's efforts to create a tracklist produced Side 2's run of strippeddown, acoustic sketches, most hovering around the 2-minute mark. ${ }^{27}$ Indeed, the string of "Rocky Raccoon," "Don't Pass Me By," "Why Don't We Do It in the Road," and "I Will" almost deliberately frustrates listeners expecting Pepper's lush sonic landscapes and social commentary. ${ }^{28}$ On the album's most direct portrait of loss, the Side 2 closer "Julia," Lennon's elegy for his mother doubles as a farewell to Pepper's maximalism: quoting Kahlil Gibran, Lennon opens by confessing, "Half of what I say is meaningless." Fittingly, "Julia" refutes the temptation to mistake the White Album's length for a scaling up of ambition: Lennon says his meaningless phrases not to craft a grand social statement, but "just to reach" his dead mother.

On Side Four's "Savoy Truffle," post-Pepper weariness meets George Harrison's own unease with over-interpreting listeners. While the song takes inspiration from Eric Clapton's "sweet tooth" .. . Dave Rybaczewski observes that it also works to "distance [Harrison] from spiritual songwriting," as evidenced in his September 1968 interview with New Musical Express: "I now want to write songs that don't have any meaning because I'm a bit fed up with people coming up and saying, 'Hey, what's it all about? What does it mean?"' (quoted in Rybaczewski). Ostensibly trading spirit for the body, the song features a litany of sweets in the verses, accompanied by the refrain's warning about getting teeth extracted "after the Savoy truffle." Yet the song also anticipates disappointment with George's turn from philosophical meditation, via a slippage between "I" and "You." While verses cast Harrison as enslaved by indulgence ("I feel your taste all the time we're apart"), the refrain and bridge chide "you" for shortsightedness ("You might not feel it now/But when the pain cuts through, you're going to know"). Furthermore, this "you" has a sweet tooth when it comes to songs, not just food. The line "What tastes sweet turns so sour" precedes the couplet "We all know 'Obla-Di-Bla-Da'/But can you show me where you are?", implying that the listener, not Harrison himself, desires the facile life-isgood anthems emblematized in McCartney's reggae pastiche. In questioning whether fault lies with artist or listener, George adopts the Decadent strategy of "ironiz[ing] and revalu[ing] the judgement" of scandalized readers (Constable et al., 12). Like Wilde's degenerating painting of Dorian 
Gray, in which "each major character in the novel finds his own reflection" (Constable et al. 20), Harrison challenges listeners to consider whether his "meaningless" song simply reflects their own vacuity.

\section{ANIMAL BODIES, ABHUMAN BLUES}

Harrison's ode to decaying teeth reminds us that, even in its lighter moments, the White Album obsesses over bodies in disrepair: lizardlike, gluttonous, tired, subject to mutilation. This thematic focus resonates with the role bodies played in figuring late Sixties Britain's national and artistic decay. "Socially infectious" drug use, in the words of a 1965 government report, metaphorized cultural dissolution as biological threat (Brain et al., 3). Meanwhile, Michael Brake observes, press descriptions of hippies focused on their unruly bodies, with images of nakedness proving that the counterculture was "degrading, decadent, and plain daft" (quoted in Brake 96). LGBT bodies also endured increased surveillance, as backlash to the liberalizing Sexual Offences Bill of 1967 produced a spike in arrests and convictions for "indecency" (Weeks quoted in Donnelly 120); so, too, did the bodies of abortion-seeking women come under scrutiny, as a 1967 bill to legalize abortion sparked vigorous opposition from the Catholic church and a "cross-party alliance" of politicians (Donnelly 120). TV footage of Vietnam war casualties, combined with images of clashes between protestors and police in London and Paris, also made 1968 a year in which disfigured figures occupied the public imagination. ${ }^{29}$

The White Album's engagement with such images can be understood via a term the Victorianist Kelly Hurley has coined to describe fin de siècle fiction, the "abhuman." Abhuman bodies "occupy the threshold between two terms of an opposition, like human/beast, male/female, or civilized/ primitive" (190); Dracula, Hyde, and the humanoid animals of The Island of Dr. Moreau all embody abhumanity, as criminality, sexual deviancy, and racial inferiority, then thought of as harbingers of devolution, take form in their "metamorphic bodies" (194)..$^{30}$ However, abhuman bodies also warrant pity, even indignation: in The Island of Dr. Moreau, the narrator's disgust with the half-animal "Beast-Men" alternates with pity and umbrage at the "aimless" scientific experiments that created them. The White Album's drugged, animalized, and zombified bodies similarly suspend the listener between revulsion and sympathy. 
Abhumanness lurks within "Happiness is a Warm Gun," which flirts with declinist fears of the counterculture before subverting them. The opening section likens a "girl ... acquainted with the touch of a velvet hand" to a "lizard on a windowpane"; her counterpart, a "man in the crowd" whose "hands are busy working overtime," creates a "soap impression of his wife which he ate and donated to the National Trust." This oblique allusion to "defecation on common land owned by the National Trust," a literal soiling of the public good (Derek Taylor, quoted in Turner 157), likely evaded most listeners; nonetheless, the juxtaposition of both "girl" and "man" with a watchful lizard casts them as reptilian, poised to destroy civilized norms through their vaguely sinister behavior. The second section's refrain-"I need a fix 'cause I'm going down"-links the junkie to this lizardlike duo, lurching toward his "fix" with no more autonomy than an animal crawling down a window. ${ }^{31}$ However, in the third section, Lennon's ecstatic delivery of the title phrase presents the gun enthusiast as the ultimate degenerate. The song's deviants are eclipsed by a trigger-happy persona who "know[s] nobody can do me no harm." With a chorus of backing vocals ("bang bang shoot shoot") delivered in a "feigned doo wop euphoria" (Riley 267), the final section suggests such psychotic aggression as a "socially infectious virus" (quoted in Creasy) in its own right.

Sides 2 and 3 revisit the blurred human-animal boundary, with the sequence of "Blackbird," "Piggies," and "Rocky Raccoon" (doubtlessly intended as a joke) presenting sympathetic sketches of either anthropomorphized animals or animalized humans. In "Blackbird," being animal means being free, with all the peril that freedom entails. Whether or not American civil rights inspired the song (a matter of some debate), "Blackbird" evokes a situation that would have been familiar to Britain's nonwhite immigrants, having migrated from the Commonwealth only to face a rising tide of xenophobia..$^{32}$ In an ambiguous turn of phrase, McCartney's titular bird flies not into sunshine, but "into the light of the dark black night." If decline here manifests in "broken wings," the gentle acoustic setting encourages identification with that frailty, now compounded by the total darkness in which the bird must find its way.

Indeed, all three songs subvert the abhorrence, implicit in degeneration theory, of becoming-animal. "Piggies" sketches an allegorical society a la George Orwell's Animal Farm, in which the main distinction lies not between human and animal, but between the large and "little piggies", for whom "life is getting worse." Even on "Rocky Raccoon," a minor tribute to Western tropes of shootouts and saloons, the titular character is deigned 
animal-like because he suffers harm, not because he threatens it: ostensibly, he resembles a raccoon because he was "hit . . . in the eye," producing a black mark not unlike a racoon's signature characteristic. Shortly thereafter, McCartney glorifies primal instinct on "Why Don't We Do It in the Road?” Inspired by watching monkeys copulating, the song's lyrics lack literal reference to simian sex; nonetheless, the parade of lizards, birds, pigs, and raccoons frames the titular question as an invitation for humanity to become animal, the rock ' $n$ ' roll equivalent of Moreau's Beast-Men. The brief track's immediate segue into the sentimental "I Will," also by McCartney, then presents a Hyde-Jekyll dichotomy to do Robert Louis Stevenson proud. Recalling Lombroso's examination of the "born delinquent," the sequence reveals a primitive drive to break taboos lurking beneath a facade of self-control, as the furtive glee of the line "no one will be watching us" becomes the decorous promise, "I will wait a lonely lifetime." Indeed, one can read the latter song's title as a sly answer to the former's: the person who ends up "doing it in the road" may, in another moment, be the purveyor of well-mannered balladry.

The album's abhuman fixation reaches a pinnacle on "Yer Blues," which functions as a kind of sequel to the side 2 track "I'm So Tired." If the latter suspends Lennon between wakefulness and sleep, "Yer Blues" channels the horror classic of 1968, Night of the Living Dead, by straddling life and death itself. While Lennon sings, "Yes I'm lonely/Wanna die," the song's lumbering tempo, anchored by McCartney's bass, suggests a moving body that has already died, a corpse lurching across a graveyard. Elsewhere, Lennon states that he isn't actually "dead already," but the album's most graphic image of bodily decay indicates otherwise: with "the eagle picks my eye/The worm he licks my bones," romantic notions of oneness with nature (expressed on Lennon's own "Dear Prudence") give way to a grisly "oneness" with eagle and worm. "Yer Blues" thus verges on affirming critiques of hippie deviance, as one of the counterculture's spokesmen seems to have "enlightened" himself into living death.

However, Lennon also sings that he feels as suicidal as "Dylan's Mr. Jones," the protagonist of Bob Dylan's “Ballad of a Thin Man." Lost in a maze of surreal situations, the haplessly square Mr. Jones prompts the song's scornful refrain: "Something is happening here, but you don't know what it is, do you, Mr. Jones?" Lennon's reference to this avatar of bourgeois befuddlement may be "mocking," as Peter Doggett suggests, but it also offers empathy, casting the suicidal longing to embrace decline as a universal condition, rather than the provenance of nihilistic youth. Indeed, Lennon 
ironically reappropriates Maharishi-inflected language with the lines "I am of the universe/And you know what it's worth": his cosmic state entails not bliss, but a death wish common to "Mr. Jones" and bohemian alike.

\section{AMBIVALENT CONCLUSIONS AND NEO-VICTORIAN DECLINISM: SAYING GOODNIGHT, THEN AND NOW}

I have argued that the White Album shows profound affiliation with late Victorian fictions of loss. As Ian Marshall notes, the album's stylistic and thematic diversity recalls Mikhail Bakhtin's theory of the novel as "dialogic" (15), a site of "unresolved situations" through which "competing worldviews speak [but] neither (or none of many) emerges as the dominant voice" (24). However, where Marshall emphasizes the postmodernity of the album's Bakhtinian dialogics, I have suggested that those dialogics restage fin de siècle tropes of sociopolitical, aesthetic, and bodily degeneration. Stephen Arata observes the perpetual entanglement of these forms of decline, such that "a discussion of any one of them led to consideration of the other two" (2). In that vein, I want to highlight two moments on the White Album where civilizational collapse, artistic fragmentation, and bodily decay converge: "Helter Skelter" and the closing "Revolution \#9"/"Goodnight" sequence.

Placed a few songs after "Yer Blues" on Side 3, "Helter Skelter" ratchets up that song's preoccupation with bodies stretched to the point of breakage, starting with the title's literal reference to a British fairground ride. McCartney's lyrics include veiled threats like "Don't let me break you"; he, Lennon, and Harrison strike their guitars so hard they wobble out of key; and Ringo Starr screams at the conclusion, "I've got blisters on my fingers." The primal brutality inherent to the song's music and lyrics thus extends the album's motif of animal reversion. Meanwhile, as the bodies represented in the song are "coming down fast", its form also degenerates. In the antithesis to the definitive piano chord that closes "A Day in the Life," "Helter Skelter" concludes with three fade-outs, challenging the listener to consider "why a song really comes to an end" (Whitley 122). Finally, the term "helter skelter" also connotes sociopolitical panic, a failure of law and order, relaying McCartney's stated intention to capture "the rise and fall of the Roman Empire" (Miles, 488). "Helter Skelter" thus alternately functions as an anthem for deviant flesh, a rejection of classicist song form, and a demented historical parable about imperial life cycles. 
The pairing of "Helter Skelter" and Harrison's hushed "Long, Long, Long," which cap off Side 3, foreshadows the closing "Revolution \#9" "Goodnight" sequence on Side 4, a climactic portrait of destruction?and, possibly, rebirth. Described by Lennon as "an unconscious picture ... of revolution," the song implies the degeneration of progress itself in its very title; "Revolution \#9," as Carleton Wilkinson observes, reduces the present upheaval to "one in a revolving door of revolutions" (193). As Wilkinson goes on to note, the track's myriad "sounds of mass experience" (194), combined with clips of "flames," "gunfire" and "whooping sounds" (221), render it an "apocalyptic vision" in which "a mindless crowd ... channel[s] its own groupthink momentum into violence and destruction" (227).

What to make, then, of the track's transition into the Hollywood strings of "Goodnight"? Political anarchy gives way to a soothing authority figure; avant-garde sound collage segues into a 1930's musical throwback; the threat of bodily evisceration turns into a reverie of childlike slumber. One can read "Revolution \#9" as a child's late-night boogeyman, dispelled by lullaby; yet "Goodnight" also comprises a sarcastic kiss-off to the civilization destroyed in "Revolution \#9." ${ }^{33}$ That both interpretations are possible returns us to the terrain of late Victorian novels, which waver between vanquishing degeneration and presenting its inevitability. Though Dracula is turned to dust, his death by knives (rather than the requisite stake) results in what Nina Auerbach and David Skal describe as a "supposed death riddled with ambiguity" (325): the monster may return. ${ }^{34}$ War of the Worlds closes with the Martians defeated, but with the narrator suffering "an abiding sense of doubt" (286), convinced that his peers underrate "the possibility of another attack" (284). So, too, does Dorian Gray's deterioration into a corpse "loathsome of visage" function both as morally satisfying comeuppance and as tragic loss of beauty. The "Revolution 9/Goodnight" finale adopts the same strategy as these texts: inverting the line in "Revolution 1," it counts us in for destruction, then (somewhat fantastically) out of it.

That the Beatles' self-titled album begins and ends as a neo-Victorian meditation on loss may be appropriate, considering cultural declinism's role in shaping their identity. Yet does not such an analysis risk the very over-interpretation Lennon scorned on "Glass Onion"? In accounting for the album's fin de siècle fixations, we should consider Terrence Riley's examination of Sgt. Pepper and the film Yellow Submarine. Taking cues from scholarship on cultural memory, Riley argues that both Sgt. Pepper's and Yellow Submarine's neo-Victorian qualities stem from a "communal recollection" of the period involving the Beatles, public signifiers of Victoriana ("art, 
architecture, literature," 42), and a collective imagination "well stocked with images, themes, characters, songs, and fragments of plots from the long British nineteenth century" (51). The Beatles may have channeled these influences, but they did so instinctively, without the intent to create a period piece. So, too, might the White Album display an unconscious practice of cultural memory, responding to its moment by resurfacing narratival elements through which the Victorians, still beloved in Sixties Britain, had processed their own fears of decline.

The album also functions as a paradoxical memory of its own future, anticipating declinism's return to twenty-first-century Britain. Brexit's challenge to the EU stemmed from "a mutated form of British declinism" (Drea 118); a corollary rise in anti-immigrant attitudes has produced "dehumanizing metaphors [depicting] immigrants as "parasites, leechers, or bloodsuckers," that is, animalistic harbingers of decay (Mulsolff 41); and according to a 2018 Cambridge/YouGov survey, 6o percent of Britons believe in conspiracy theories (Leal 9), a phenomenon whose corollary "tendency to perceive agency and intentionality where it does not exist" (Douglas et al. 539) produces precisely the kinds of symptomatic readings of pop culture artifacts, cast as evidence of degenerate impulses, that bedeviled the Beatles. ${ }^{35}$ To the extent that the White Album rearticulates and challenges late Victorian apprehensions, it also invites reflection on how Victorian the nation remains, not least in its resurgent fear that now, at last, it's time to say goodnight.

LUCAS KWONG is an assistant professor of English at New York City College of Technology. His scholarship on Victorian fantastic fiction, religion, and colonialism has been published in Victorian Literature and Culture and Journal of Narrative Theory. He is the assistant editor for New American Notes Online, an interdisciplinary scholarly journal. journal. He lives in Brooklyn with his wife.

\section{NOTES}

1. For example, Osteen writes that the album's length and diversity "[are] not Victorian, but postmodernist" (1).

2. See Macdonald's observation that "shadows lengthen over [the White Album] as it progresses" (328) and Joan Didion's description of the album as "ominous and disturbing" (Kakutani). 
3. For more on Roman decline in late Victorian discourse, see Hagerman 108-28 and Vance.

4. For more about Victorian scholarly prohibitions on miscegenation, see Harris.

5. For more on this view of British India, see Bakshi.

6. Arata's centrality to my argument risks recapitulating his oversights. As Nicholas Daly has pointed out, late Victorian texts voice not only degeneration anxiety, but also "the ethos of rising professionalism and expertise" (8). Nonetheless, Victorianist scholars widely assume the salience of British declinism to fin de siècle texts. Arata's readings of "reverse colonization" builds on Patrick Brantlinger's treatment of "imperial Gothic" literature's "insistent images of decline and fall" (229); his examination of devolving flesh resonates with Kelly Hurley's treatment of "abhuman" bodies noted elsewhere in this article; and his examination of literary art's ambivalent relationship to declinism in this era finds confirmation in Gerardine Meany, Matthew Potolsky, and Daniel Pick's respective treatments of New Woman writers, Decadent poetics, and urban Gothic novels.

7. See Grant's discussion of 1960's "state of the nation" literature. For more about postwar Britain's imperial nostalgia, see Schwartz, Ward, Burkett, and Bailkin.

8. See Simonelli's discussion of fears of a "tidal wave" of American cultural influence (8) and Lindberg et al.s examination of the same (82-83).

9. For more on public perceptions of Mod-Rocker violence, see Cohen.

10. For more on how "the Beatles were courted by politicians anxious to be associated with the heroes of the nation's youth" (Tranmer 91), see Tranmer.

11. See also Martin Lewis's description of the album as a salute to "fading memories of the vanishing British Empire," noting that "A Day in the Life" foregrounds "two enduring architectural symbols of the Victorian era-the House of Lords and the Royal Albert Hall" (Lewis). Sandbrook also observes that "the late Victorian or Edwardian music hall" inspired the album's music and artwork (Sandbrook 439), while Jeff Slate writes that the album reveals a "love of all things British (music hall, Lewis Carroll, and Victorian-era England)."

12. See Everett 137, Womack 62, Macdonald 309.

13. For more about "I'm Backing Britain," see Sandbrook 595.

14. Released the same day as the White Album, The Kinks Are the Village Green Preservation Society ventriloquizes this contemporary fondness for Victorian monsters on its title track: "We are the Sherlock Holmes English-speaking Vernacular/God save Fu Manchu, Moriarty and Dracula." For more about "passing" as a strategy of the reverse colonizer, see Arata 124-25.

15. Riley (263) and Roessner (157) also note these influences.

16. For more on how the Monday Club spread this conflation of student activism and foreign influence, see McNeil. As he notes, one member decried leftist "internationalists" who influenced "university students and other entrepreneurs" (quoted in McNeil 743).

17. The Beatles had given several interviews about India by the White Album's release, with Lennon somewhat ruefully calling it a "mistake" (Lennon \& McCartney, "Interview on the Tonight Show with Joe Garagiola"). 
18. A 1967 interview with Lennon showcases fears of "Eastern" youth culture, as the interviewer frets about the "moral issues with transcendental meditation" ("What I Believe"). Elsewhere, a People article titled "Think Again, Beatles!" accuses the Beatles of promoting a form of meditation suitable for "Eastern countries," where "hot climate and general poverty is conducive to contemplation and inactivity" (Lester 10).

19. For more on Dracula as a symbol of non-Christian spirituality, see Kwong.

20. As Everrett observes, George’s "distorted Fender Telecaster introduces a dirtiness not heard before" on a Beatles record (168).

21. Whether Lennon read the Kipling story is unclear, but on the 1973 song "You Are Here," Lennon reworks lines from Kipling's "The Ballad of East and West" (Goodden).

22. For more on America's centrality to "Greater Britain," see Bell.

23. See Simonelli 115-16 for the British Establishment's response to drug culture.

24. The expectation to make up for Magical Mystery Tour amplified the stakes of a question posed to McCartney and Lennon in a June 1968 interview: "When you produce something of such high standards as [Sgt. Pepper], don't you think that you've really got to strive to produce something a bit better?" ("Interview with Kenny Everett of Radio London").

25. Sadly, Lennon's critique of symptomatic reading was not clear enough. "Glass Onion," "I'm So Tired," "Don't Pass Me By," and "Revolution 9" all became part of the "Paul is Dead" conspiracy theory (Womack 716). Meanwhile, as Devin McKinney notes, Charles Manson found endorsements of his theories throughout the album (300).

26. Arata also cites Arthur Waugh as another who lamented a lost era of literary greatness (12). In a 1900 essay, Waugh writes, "English fiction seems again to be lost in a very wilderness of indecision" (102).

27. See Lewisohn 162 for details about this sequencing session.

28. Indeed, interviews prior to the White Album's release suggest that the Beatles were already defensive about Pepper comparisons, and wanted to emphasize the upcoming release's contrasting simplicity. "What we're trying to do is rock 'n' roll, 'with less of your philosorock,' is what we're saying to ourselves," Lennon said to Rolling Stone (Colt, 8). Meanwhile, McCartney observed on Radio Luxembourg, "'On "Sgt Pepper" we had more instrumentation than we'd ever had ... but we didn't really want to go overboard like that this time" ("Interview with Radio Luxembourg").

29. For more about confrontation between British police and protestors in 1968 , reports of which (over)emphasized the threat of violence, see Donnelly 143-150.

30. Hurley 194-97.

31. The lizard image mirrors a moment in Dracula when Harker witnesses the Count crawling down the side of his castle, "just as a lizard moves along a wall" (32).

32. Turner details the "conflicting stories" concerning the inspiration for "Blackbird," which McCartney has either identified as "hear[ing] a blackbird sing" in Rishikesh or "racial tension in America" (160). 
33. Whitley notes Lennon's assertion that "Goodnight" was intended to sound "insincere" and "corny" (122).

34. See also Arata's observation that the ending "exarcerbate[s] the anxieties [it is] intended to assuage" by implying that Jonathan Harker cannot escape his "terrible memories" (130), as well as Tammy Ho on the novel's "ambiguous ending" (102).

35. Paul McCartney recently came under scrutiny from Illuminati conspiracy theorists for posting a drawing of a pyramid to Twitter ("Is Paul McCartney In The Illuminati?"). Such theorists also claim to find signifiers of Illuminati membership in the lyrics and music video imagery of Jay-Z, Beyonce, Nas, Kanye West, and other hip hop artists (Partridge 200, Gosa 194). Meanwhile, the Pizzagate conspiracy theory alleges that the lyrics and names of various punk bands betray involvement in an international pedophile ring (Tempey, Merlan 73). Elsewhere, films such as Frozen and Star Wars: The Last Jedi regularly elicit conservative criticism for subliminally promoting "gay culture themes" (Pulver, Merlan 73) and an "SJW' agenda" (Bay), anti-Decadent accusations which often, though not always, supplement conspiracy theories about Hollywood's liberal agenda.

\section{WORKS CITED}

Adelt, Ulrich. Blues Music in the Sixties: A Story in Black and White. New Brunswick: Rutgers University Press, 2010.

Arata, Stephen. Fictions of Loss in the Victorian Fin De Siècle: Identity and Empire. Cambridge: Cambridge University Press, 1996.

Auerbach, Nina, and David Skal, eds. Dracula (Norton Critical Editions) by Bram Stoker. 1st ed. New York: Norton, 1996.

Bailkin, Jordanna. The Afterlife of Empire. Berkeley: University of California Press, 2012.

Baldwin, P. M. "Liberalism, Nationalism, and Degeneration: The Case of Max Nordau." Central European History 13, no. 2, 1980: 99-120.

"Ballyhoo." Somerset County Herald and Taunton Courier [Somerset, England], 23 November 1963, 1.

Bay, Morten. "Weaponizing the haters: The Last Jedi and the strategic politicization of pop culture through social media manipulation." First Monday 23, no. 11 (2018), Web only, doi.org/10.5210/fm.v23i11.9388.

Beatles, The. The Beatles. EMI Records, 1968. CD.

Bell, Duncan. "Envisioning America." The Idea of Greater Britain: Empire and the Future of World Order, 1860-1900, Princeton: Princeton University Press, 2009, 231-59.

Brake, Michael. The Sociology of Youth Culture and Youth Subcultures: Sex and Drugs and Rock ' $n$ ' roll? London: Routledge \& Kegan Paul, 1980. 
Brantlinger, Patrick. Rule of Darkness: British Literature and Imperialism, 18301914. Ithaca: Cornell University Press, 2013.

Brown, Callum G. The Death of Christian Britain: Understanding Secularisation 1800-2000, 2nd ed. London: Routledge, 2009.

Buchanan, Robert. "The Voice of the Hooligan." The Contemporary Review 76 (December 1899): 774-89, http://www.robertbuchanan.co.uk/html/ hooligan.html.

Burkett, Jodi. Constructing Post-Imperial Britain: Britishness, 'Race' and the Radical Left in the 1960s. Basingstoke: Palgrave Macmillan, 2013.

Chibnall, Steve. "Whistle and Zoot: The Changing Meaning of a Suit of Clothes." History Workshop Journal, 20 no. 1 (1985): 56-81, https://doi.org/10.1093/ hwj/20.1.56.

Cohen, Stanley. Folk Devils and Moral Panics: The Creation of the Mods and Rockers. Psychology Press. 3rd ed. New York: Routledge, 2002.

Colt, Jonathan. Back to a Shadow in the Night: Music Writings and Interviews, 1968-2001. Hal Leonard, 2002.

Constable, Liz et al. Introduction. Perennial Decay: On the Aesthetics and Politics of Decadence, edited by Constable et al. Philadelphia: University of Pennsylvania Press, 1999, 1-34.

Coopey, Richard. "Popular Imperialism: The British Pop Music Industry 19501975," working paper, Business History Unit, London School of Economics, www.erim.eur.nl/fileadmin/erim_content/documents/Coopey_Popular_ Imperialism.pdf.

Creasy, Martin. Beatlemania! The Real Story of the Beatles UK Tours 1963-1965. London: Omnibus, 2011. Google Books, https://books.google.com/ books?id=NeaaAwAAQBAJ\&printsec=frontcover\&vq=socially+infectious + virus\&source=gbs_ge_summary_r\&cad $=0 \# \mathrm{v}=$ onepage\&q\&f $=$ false.

Daly, Nicholas. Modernism, Romance and the Fin De Siècle: Popular Fiction and British Culture. Cambridge: Cambridge University Press, 2000.

Davis, Todd F., and Kenneth Womack, eds. Reading the Beatles: Cultural Studies, Literary Criticism, and the Fab Four. New York: State University of New York Press, 2006.

DeCoux, Jessica. "Marie Corelli, Wormwood, and the Diversity of Decadence." Cahiers victoriens et édouardiens, vol. 74 (Autumn 2011), 89-106, Open Edition, https://journals.openedition.org/cve/1337.

Donnelly, Mark. Sixties Britain: Culture, Society, and Politics. Pearson Longman, 2005.

Doggett, Peter. The Art and Music of John Lennon. Omnibus, 2009. Google Books, https://books.google.com/books/about/The_Art_And_Music_Of_John_ Lennon.html?id $=16 \mathrm{~h} 6 \mathrm{ju} \_-5 \mathrm{dYC} \&$ printsec $=$ frontcover\&source $=\mathrm{kp} \_$read_ button\# $\mathrm{v}=$ onepage \&q\&f=false.

Douglas, Karen M. et al. “The Psychology of Conspiracy Theories." Current Directions in Psychological Science 26, no. 6 (2017), 538-42, doi. org/10.1177/0963721417718261. 
Drea, Eoin. "The Empire Strikes Back: Brexit, History and the Decline of Global Britain." European View 18, no. 1 (2019), 118-19. Sage Journals, doi. org/10.1177/1781685819844194.

Everett, Walter. The Beatles as Musicians: Revolver through the Anthology. New York: Oxford University Press, 1999.

Farrow, Mia. What Falls Away: A Memoir. New York: Bantam, 1997.

Franklin, J. Jeffrey. The Lotus and the Lion: Buddhism and the British Empire. Ithaca: Cornell University Press, 2008.

Goodden, Joe. "You Are Here." The Beatles Bible, https://www.beatlesbible.com/ people/john-lennon/songs/you-are-here/.

Gosa, Travis L. "Counterknowledge, racial paranoia, and the cultic milieu: Decoding hip hop conspiracy theory." Poetics 39, no. 3 (2011), 187-204, doi.org/10.1016/j.poetic.2011.03.003.

Grant, Matthew. "Historians, the Penguin Specials and the 'State-of-the-Nation' Literature, 1958-64." Contemporary British History 17, no. 3, 2003, 29-54, $10.1080 / 13619460308565450$.

Haggard, H. Rider. She: A History of Adventure. New and Revised Edition. London: Longmans, Green and Co, 1896.

Hagerman, C. Britain's Imperial Muse: The Classics, Imperialism, and the Indian Empire, 1784-1914. New York: Springer, 2013.

Harris, Trevor. "Britannia super omnes: Race theory and The Imperial Sentiment in Victorian Britain." Faradoxe(s) victorien(s) - Victorian Paradox(es), edited by William Findlay, 29-42. Tours: Presses universitaires François-Rabelais, 2005, books.openedition.org/pufr/4676, accessed 29 Jul 2019.

Ho, Tammy Lai-Ming. Neo-Victorian Cannibalism: A Theory of Contemporary Adaptations. New York: Springer, 2019, accessed 29 Jul 2019.

Kimsey, John. "Beatles Unplugged: The White Album in the Shadow of Rishikesh." Osteen, 72-90.

Kinks, The. Lyrics to "The Village Green Preservation Society." Genius, 2014, https://genius.com/The-kinks-the-village-green-preservation-society-lyrics.

Kipling, Rudyard. "The Tomb of His Ancestors." The Day's Work, Doubleday, 1898, 109-156.

. Kim. Edited by Alan Sandison. Oxford University Press, 2008.

Kwong, Lucas. "Dracula's Apologetics of Progress." Victorian Literature and Culture 44, no. 1 (2016), 111-29, doi.org/10.1017/S1060150315000455.

Leal, Hugo et al. "YouGov-Cambridge Centre for Public Opinion Research Survey on Conspiracy Theories (Great Britain)." 13-23 August 2018. https:// d25d2506sfb94s.cloudfront.net/cumulus_uploads/document/5j57dtwlco/ YGC\%20Conspiracy\%2oTheories\%2o(GB).pdf.

Lennon, John, and Paul McCartney. Interview on the Tonight Show with Joe Garagiola, 14 May 1968. Transcribed by Jay Spangler. The Beatles Ultimate Experience, http://www.beatlesinterviews.org/db1968.05ts.beatles.html.

Lennon, John. “What I Believe." Daily Sketch, 9 October 1967, 18. Transcribed by Jay Spangler. The Beatles Ultimate Experience, http://www.beatlesinterviews. org/db1967.1009.beatles.html. 
Lennon, John, et al. Interview with Kenny Everett of Radio London, 5 June 1968. Transcribed by Jay Spangler. The Beatles Ultimate Experience, http://www. beatlesinterviews.org/db1968.0605.beatles.html.

Lester, Wilfred. “Think Again, Beatles!” The People, 3 September 1967, 10. The British Newspaper Archives, https://www.britishnewspaperarchive.co.uk/ viewer/bl/oooo729/19670903/087/0010.

Lewis, Martin. "With 'Sgt. Pepper', the Beatles Celebrated Britain's Lost Empire, and Found It a New Role." Variety, 25 May 2017, variety.com/2017/music/ spotlight/with-sgt-pepper-the-beatles-celebrated-britains-lost-empire-andfound-it-a-new-role-1202443612/.

Lewisohn, Mark. The Beatles: Recording Sessions. Bourbon, IN: Harmony Books, 1988.

Lindberg, Ulf, et al. Rock Criticism from the Beginning: Amusers, Bruisers, and Cool-headed Cruisers. New York: Peter Lang, 2005.

Longinotti, Edward. "Britain's Withdrawal from East of Suez: From Economic Determinism to Political Choice." Contemporary British History 29, no. 3 (2015): 318-40.

Lord Brain et al. The Second Report of the Interdepartmental Committee on Drug Addiction. Her Majesty's Stationery Office, 1965. Salvation Army Centre for Addiction Services and Research Online Library, http://www.dldocs.stir. ac.uk/documents/2nd-brain-report.pdf.

Macdonald, Ian. Revolution in the Head: The Beatles' Records and the Sixties. 3rd ed. Chicago: Chicago Review Press, 2007.

Marshall, Ian. "I am he as you are he as you are me and we are all together': Bakhtin and the Beatles." Davis and Womack, 9-35.

Mazzarello, Paolo. "Cesare Lombroso: An Anthropologist between Evolution and Degeneration." Functional neurology 26, no. 2 (2011): 97-101.

McKinney, Devin. Magic Circles: The Beatles in Dream and History. Cambridge, MA: Harvard University Press, 2003.

Mcneil, Daniel. “The Rivers of Zimbabwe Will Run Red with Blood': Enoch Powell and the Post-Imperial Nostalgia of the Monday Club." Journal of Southern African Studies 37, no. 4 (2011), 731-45.

Meany, Gerardine. "Decadence, Degeneration and Revolting Aesthetics: The Fiction of Emily Lawless and Katherine Cecil Thurston." Colby Quarterly 36, no. 2 (2000): 157-75.

Miles, Barry. Paul McCartney: Many Years from Now. New York: Henry Holt and Company, 1997.

Negus, Keith. "Narrative, Interpretation, and the Popular Song." Musical Quarterly 95, no. 2/3 (2012): 368-95, www.jstor.org/stable/41811631.

McCartney, Paul. Interview with Radio Luxembourg, 20 November 1968. Transcribed by Jay Spangler. The Beatles Ultimate Experience, http://www. beatlesinterviews.org/db1968.112o.beatles.html.

Interview with ITV, 19 June 1967. Transcribed by Jay Spangler. The Beatles Ultimate Experience, http://www.beatlesinterviews.org/db1967.0619.beatles.html. 
Merlan, Anna. Republic of Lies: American Conspiracy Theorists and Their Surprising Rise to Power. New York: Metropolitan, 2019.

Musolff, Andreas. "Dehumanizing metaphors in UK immigrant debates in press and online media." Journal of Language Aggression and Conflict 3, no. 1 (2015): 41-56, doi.org/10.1075/bct.93.02mus.

Norman, Philip. John Lennon: The Life. New York: Doubleday, 2009.

Orlando, Jordan. "The Accidental Perfection of the Beatles' White Album." New Yorker, 10 November 2018, www.newyorker.com/culture/cultural-comment/ the-accidental-perfection-of-the-beatles-white-album. Accessed 29 July 2019.

Osteen, Mark, ed. The Beatles through a Glass Onion: Reconsidering the White Album. Ann Arbor: University of Michigan Press, 2019.

Osteen, Mark. "Introduction: Part of Everything: The Beatles through a Glass Onion." Osteen, 1-34.

Partridge, Christopher. "Popular Music, Conspiracy Culture, and the Sacred." Handbook of Conspiracy Theory and Contemporary Religion. Leiden: Brill, 2018.

Pater, Walter. The Renaissance: Studies in Art and Poetry. Rpt ed. Grants Pass, OR: Courier, 2013.

Pick, Daniel. Faces of Degeneration: A European Disorder, C. 1848-1918. Cambridge: Cambridge University Press, 1993.

Potolsky, Matthew. "In Praise of Decadence: The Epideictic Mode from Baudelaire to Wilde." Decadent Poetics. Palgrave Studies in NineteenthCentury Writing and Culture, edited by J. D. Hall and A. Murray, 100-115. Basingstoke: Palgrave Macmillan, 2013.

Pulver, Andrew. "Frozen Lambasted as Pro-Gay Propaganda by Christian Pastor." Guardian 12 March 2014, https://www.theguardian.com/film/2014/mar/12/ frozen-gay-propaganda-christian-pastor-colorado.

"Put out less flags." New Statesman, 19 January 1968, 85.

Riley, Terrance. "The Beatles as Performers of Cultural Memory." Neo-Victorian Studies 9, no. 1 (2016), 32-54.

Riley, Tim. Tell Me Why: The Beatles: Album by Album, Song by Song, the Sixties and After. First Da Capo press ed. Boston: Da Capo, 2002.

Roessner, Jeffrey. "We All Want to Change the World: Postmodern Politics and the Beatles' White Album." Davis and Womack, 147-60.

Rybaczewski, Dave. “'Savoy Truffle' History.” Beatles Music History!, DKR Products, Web site, http://www.beatlesebooks.com/savoy-truffle.

Sandbrook, Dominic. White Heat: A History of Britain in the Swinging Sixties. New York: Little, Brown, 2006.

Schwartz, Roberta Freund. How Britain Got the Blues: The Transmission and Reception of American Blues Style in the United Kingdom. London: Routledge, 2016.

Schwartz, Bill. Memories of Empire: The White Man's World (Vol. I), New York: Oxford University Press, 2011. 
Simonelli, David. Working Class Heroes: Rock Music and British Society in the 1960 s and 1970s. Lanham, MD: Rowman and Littlefield, 2013.

Slate, Jeff. "It Was Fifty Years Ago Today." Tidal, 1 June 2017, http://read.tidal.com/ article/it-was-fifty-years-ago-today.

Stoker, Bram. Dracula. New York: Doubleday, 1897.

Supple, Barry. "Official Economic Inquiry and Britain's Industrial Decline: The First Fifty Years." The State and Economic Knowledge: The American and British Experiences, edited by Mary O. Furner and Barry Supple, 325-53. Cambridge: Cambridge University Press, 2002.

Taylor, Anthony J. W. “Beatlemania” and Mass Hysteria-Still a Much-Neglected Research Phenomenon." Journal of Psychology and Psychotherapy 7, no. 3 (2017), doi: 10.4172/2161-0487.1000303.

Tempey, Nathan. "What On Earth Is Pizzagate and How Did It Result in Gunfire at Comet Ping Pong?" DCist, 5 Dec 2016, https://dcist.com/story/16/12/05/ what-on-earth-is-pizzagate-why-did/.

Turner, Steve. A Hard Day's Write: The Stories Behind Every Beatles' Song. Paperback edition. London: Carlton, 1999.

Tomlinson, Jim. “Thrice Denied: 'Declinism' as a Recurrent Theme in British History in the Long Twentieth Century." Twentieth Century British History 20, no. 2 (2009): 227-51, doi.org/10.1093/tcbh/hwpo19.

Tranmer, Jeremy. "The Radical Left and Popular Music in the 196os." Preserving the Sixties: Britain and the 'Decade of Protest,' edited by Trevor Harris and Monia O’Brien Castro, 90-104. Basingstoke: Palgrave Macmillan, 2014.

Valentine, Mark. Arthur Machen. Brigend: Seren Books, 1996.

Vance, Norman. The Victorians and Ancient Rome. Hoboken, NJ: Wiley, 1997. Waugh, Arthur. "Fiction in the Nineteenth Century." Reticence in Literature and Other Papers, London: J. G. Wilson, 1915, 93-102.

Wells, H .G. The War of the Worlds. Leipzig: Bernhard Tauschnitz, 1898.

White, Allon. The Uses of Obscurity: The Fiction of Early Modernism. New York: Routledge, 1981.

Womack, Kenneth. The Beatles Encyclopedia: Everything Fab Four (Two Volumes). Santa Barbara: ABC-CLIO, 2014.

Ward, Stuart. "Introduction." British Culture and The End of Empire, edited by Stuart Ward, 1-20. Manchester: Manchester University Press, 2001.

Whitley, Ed. "The Postmodern White Album." The Beatles, Popular Music and Society, edited by Ian Inglis, 105-25. Basingstoke: Palgrave Macmillan, 2000.

Wilde, Oscar. The Picture of Dorian Gray. 1897. Project Gutenberg, https://www. gutenberg.org/files/174/174-h/174-h.htm.

Wilkinson, Carlton J. “John Lennon's 'Revolution 9.” Perspectives of New Music 46, no. 2 (2008): 190-236. JSTOR, www.jstor.org/stable/25652393. 